\title{
Co-infection of HBV in HIV Patients Attending the ICTC of Santhiram Medical College, Nandyal, Andhra Pradesh, India
}

\author{
S. Sreedevi ${ }^{*}$, V. Aarthi ${ }^{2}$ and K. Saraswathi ${ }^{1}$ \\ ${ }^{1}$ Department of Microbiology, Santhiram Medical College, Nandyal, A.P, India \\ ${ }^{2}$ Department of Microbiology, Kurnool Medical College, Kurnool, AP, India
}

*Corresponding author

\section{Keywords}

Co-infection, HBV in HIV

Patients,

HBsAg,

hepatocellular carcinoma.

\section{Article Info}

Accepted:

18 September 2016

Available Online:

10 October 2016

\section{A B S T R A C T}

The present hospital based study was carried out in order to assess the prevalence of HBV infection in HIV seropositive individuals attending ICTC of Santhiram Medical College and General Hospital, a tertiary care hospital in A.P, India. 8665 serum samples collected over a period of 6 months from individuals attending the ICTC were screened for anti HIV antibodies as per NACO protocol. Samples found to be reactive for HIV antibodies were tested for HBsAg by rapid card test as per manufacturers guidelines in serology section of Dept of Microbiology. Our study shows, out of 8665 HIV suspected cases $2.4 \%$ (211/8665) were reactive for HIV and prevalence of Hepatitis B co-infection was $8.5 \%$ (18/211). In our study the commonest risk factor for transmission of $\mathrm{HBsAg}$ was unprotected sex which was $61.1 \%$ (11/18). Maximum of co-infected patients were of age group $35-49$ years, followed by $25-34$ years. The rate of progression and complications from viral hepatitis are accelerated in patients with co-infections. After acquiring Hepatitis $b$ infection HIV infected individuals are more likely to develop chronic Hepatitis B infections leading to hepatocellular carcinoma. This represents another potential co-morbidity for patients with HIV infections. Early diagnosis and treatment increase the longevity of HIV positive patients irrespective of CD4 counts.

\section{Introduction}

HIV is a lentivirus that causes AIDS. The four major routes of transmission are unsafe sex, contaminated needles, blood or blood contaminated objects and transmission from an infected mother to her baby at birth (Perinatal transmission). Owing to shared transmission routes, HBV infections are highly prevalent among HIV infected persons.
HBV coinfections among HIV positive individuals is of utmost importance due to the under lying consequences such as more rapid progression of liver disease including accelerated fibrosis, cirrhosis and HCC and higher liver related mortality and morbidity. In presence of $\mathrm{HIV}, \mathrm{HBV}$ is known to have higher viral load and can result in greater hepatic damage. The data on HBV coinfection among HIV infected patients is 
scarce in South India. Hence the present study was under taken to estimate the prevalence of $\mathrm{HBsAg}$ in HIV positive individuals attending ICTC in Santhiram General Hospital, a tertiary care center in Nandyal, A.P. and also to determine the association of HIV-HBV coinfection with age, gender of population under study.

\section{Materials and Methods}

The present study was carried out in a tertiary care hospital during a period of 1 Dec2015 to 31 May 2016. HIV antibody detection was performed by a testing algorithm using three different assays according to NACO guidelines after the mandatory pretest counselling with informed consent of the client. Reactive results for HIV antibody testing were disclosed only after post test counselling.

Prior to CD4 enumeration and starting of ART certain routine investigations are conducted in these patients. Among these investigations, screening for $\mathrm{HBsAg}$ positivity is an important prerequisite. Hence ethical considerations are not applicable.

Serology: The serum collected was tested for HIV antibodies using standard recommended procedure. Kits that were sequentially used were Immunocomb test, samples that were reactive by this method were rechecked by two other rapid tests SD Bioline, Trispot.

HBsAg was determined by a rapid card test Hepacard. All the tests were performed in accordance with the manufacturers instructions with adequate controls.

\section{Results and Discussion}

A total of 8665 samples were tested for HIV antibody out of which 211 (2.4\%) were reactive. Among the HIV reactive cases 18 cases were found to be reactive for $\mathrm{HBsAg}$ of which 11 were males and 7 were females. Maximum (47.8\%) HIV positive patients were found to be in the age group of $35-49$ years and the commonest route of transmission was seen to be through unprotected sex $(88.6 \%)$.

HIV is a RNA virus belonging to the Retroviridae family while HBV is a DNA virus belonging to Hepadnaviridae family. Co-infections with HIV and HBV is known to affect clinical outcomes in patients.

In our study, total 8665 samples were taken from HIV suspected cases. Out of which 211 $(2.4 \%)$ were reactive to HIV infection. This is comparable with the study carried out by Atul karkare et al., (2004) in central India, where the prevalence was $1.6 \%$.

In our study, the prevalence of HBV coinfection was $8.5 \%(18 / 211)$ which is similar to study carried out by Jayeeta sarkar et al., (2013) (8.3\%).

The prevalence rate of HIV-HBV coinfection varies from $7-25 \%$ in various studies (Dhanvijay et al., 1999; Ramanamma et al., 2000; Helen et al., 2010).

A hospital based study in Kolkata showed that the highest prevalence belonged to age group $31-40$ years in contrast the present study showed the highest prevalence in the age group of $35-49$ years. In all epidemiological studies, the age of acquiring infection is the major determinant of the incidence and prevalence rates.

In our study, the most common risk factor in HIV and Hepatitis B co-infected patients was by unprotected sex in heterosexuals (61.1\%), followed by $38.8 \%$ by homosexuals. 
Table.1 Total number of co-infected patients

\begin{tabular}{|l|l|l|}
\hline $\begin{array}{l}\text { Total no.of HIV } \\
\text { positive }\end{array}$ & $\begin{array}{l}\text { Total no.of HIV + } \\
\text { HBsAg positive }\end{array}$ & Percentage \\
\hline 211 & 18 & $8.5 \%$ \\
\hline
\end{tabular}

Table.2 Age distribution of co-infected patients

\begin{tabular}{|c|c|c|}
\hline $\begin{array}{l}\text { Age distribution } \\
\text { (years) }\end{array}$ & Number of patients & Percentage \\
\hline $0-14$ & 0 & 0.0 \\
\hline $15-24$ & 1 & 5.5 \\
\hline $25-34$ & 5 & 27.7 \\
\hline $35-49$ & 8 & 44.4 \\
\hline Above 50 & 4 & 22.2 \\
\hline
\end{tabular}

Table.3 Risk factors in co-infected patients

\begin{tabular}{|l|c|c|}
\hline Route of transmission & $\begin{array}{c}\text { Number of co-infected } \\
\text { patients }\end{array}$ & Percentage \\
\hline Heterosexuals & 11 & 61.1 \\
\hline Intravenous drug users & 0 & 0.0 \\
\hline Mother to child & 0 & 0.0 \\
\hline Homosexuals & 7 & 38.8 \\
\hline Blood transfusion & 0 & 0.0 \\
\hline
\end{tabular}

In a study carried out by Padmapriyadarshini et al., (2006) in India, out of $81 \mathrm{HIV}-\mathrm{HBV}$ positive patients, $82.7 \%$ were infected through sexual transmission.

In coinfected patients, the status of HIV infection and the need for ART are the major determinants in choosing an $\mathrm{HBV}$ treatment strategy. If patients do not meet criteria for HIV treatment (CD4 cell count > 350 cells $/ \mu \mathrm{l}$ ) but treatment for HBV alone is required, options include pegylated interferon alfa, adefovir 10mg, and telbivudine. HIV/HBV coinfected patients who require treatment of both infections should be treated with combination ART, which includes a back bone of nucleoside/nucleotide analogues effective against both diseases. The HIV ARV drugs tenofovir, lamivudine and emtricitabine have activity against both viruses, making them the logical choice in these patients. Tenofovir + emtricitabine or lamivudine is the preferred first line therapy. None of these agents should be used alone for the treatment of HBV due to the high risk of developing HIV drug resistance. In a study that included individuals who were naive to therapy and required treatment for both HBV and HIV, the combination of tenofovir and lamivudine was effective in suppressing HBV DNA levels and preventing the development of resistance (Dore et al., 2004).

The study documents high rate of HBV coinfection in HIV positive patients despite using $\mathrm{HBsAg}$ as the only marker of $\mathrm{HBV}$ infection in the study group. This rate of coinfection could have been higher if other 
hepatitis viral markers like HBV-DNA etc were included in the study.

The present study emphasize that a uniform protocol should be formed to screen every HIV/AIDS patient and their co partners for hepatitis B viral markers and vice versa for early detection and management. Thus this study of HIV and Hepatitis B co infection is necessary for the early starting of the treatment, which can reduce the mortality and morbidity of the patients.

\section{References}

Atul Karkare, Anup, R., Anvikar, Vikas, G., Rao. et al. 2004. HIV infection and Sexually Transmitted Diseases in Central India; Proceeding of National Symposium on Tribal Health, 8: 99.

Dhanvijay, A.G., Thakar, Y.S., Chande, C.A. 1999. Hepatitis B virus infection in HIV infected patients. Indian J. Med. Microbiol., 17(4): 167-69.

Dore, G.J., Cooper, D.A., Pozniak, A.L., et al. 2004. 903 Study Team. Efficacy of tenofovir disoproxil fumarate in antiretroviral therapy-naive and experienced patients coinfected with HIV-1 and hepatitis B virus. J. Infect. Dis., 189: 1185-92.

Helen, M., Chun, Ann, M., Fieberg, Katherine Huppler Hullsiek, et al. 2010. Epidemiology of Hepatitis B virus Infection in a US Cohort of HIVInfected individuals during the past 20 Years. Clin. Infect. Dis., 50(3): 426436.
Jayeetha Sarkar, Bhaswati Bandyopadhyay, Runu Chakrabarty, et al. 2013. HIVHBV Coinfection among Individuals attending the ICTC of a Tertiary care hospital in West Bengal, India; ISRN Virol., Article ID 180150.

Padmapriyadarshani, C., Chandrabose, J., Victor, L. et al. 2006. Hepatitis B or Hepatitis C co-infection in individuals infected with human immunodeficiency virus and effect of anti-tuberculosis drugs on liver function; J. Postgraduate Med., 52-926.

Panel on Antiretroviral Guidelines for Adults and Adolescents. 2008. Guidelines for the use of antiretroviral agents in HIV-1 infected adults and adolescents. Department of Health and Human Services, 50-1.

Ramanamma, M.V., Ramani, T.V., Suresh, B., Sonth, et al. 2000. Incidence of hepatitis B infection in vishakapatnam. Indian J. Med. Microbiol., 18(4): 17071.

Saillour, F., Dabis, F., Dupon, M., et al. 1996. Prevalence and determinants of antibodies to hepatitis $\mathrm{C}$ virus and makers of hepatitis $B$ virus infection in patients with HIV infection in Aquitaine. BMJ, 313: 461-64.

Soriano, V., Puoti, M., Peters, M., Benhamou, Y. et al. 2008. Care of HIV patients with chronic hepatitis B: updated recommendations from the HIV-Hepatitis B Virus International Panel. AIDS, 22: 1399-410.

\section{How to cite this article:}

Sreedevi, S., V. Aarthi and Saraswathi, K. 2016. Co-infection of HBV in HIV Patients Attending the ICTC of Santhiram Medical College, Nandyal, Andhra Pradesh, India. Int.J.Curr.Microbiol.App.Sci. 5(10): 523-526. doi: http://dx.doi.org/10.20546/ijcmas.2016.510.057 